\title{
Foetal haemoglobin and disease severity in sickle cell anaemia patients in Kampala, Uganda
}

\author{
Lena Mpalampa ${ }^{1 *}$, Christopher M Ndugwa ${ }^{2}$, Henry Ddungu ${ }^{3}$ and Richard Idro 4,5
}

\begin{abstract}
Background: Sickle cell anaemia (SCA) is a major chronic health problem in Uganda. In patients with SCA, the level of foetal haemoglobin ( $\mathrm{HbF}$ ) has been found to be important in influencing the clinical course of the disease. Thus populations with high levels of HbF like those in Saudi Arabia have been described as having a milder clinical course with fewer complications as compared to populations with lower levels. Disease modifying drugs can increase the $\mathrm{Hb} F$ levels and modify the presentation of SCA.

Methods: This was a cross sectional study in which we determined foetal haemoglobin levels and examined the relationship between HbF levels and disease severity in SCA patients in Mulago Hospital, Kampala, Uganda. We consecutively enrolled 216 children aged 1 year to 18 years with SCA attending the Sickle Cell Clinic at Mulago Hospital whose guardians had given consent. The history included age at onset of initial symptoms and diagnosis, number of hospitalisations and blood transfusions and other complications of SCA (cardiovascular accidents, avascular hip necrosis and priapism). A detailed physical examination was performed to assess the current state and help describe the disease severity for each patient. Blood samples were drawn for HbF levels. HbF levels $\geq 10 \%$ was defined as high.

Results: Of the 216 children, (80) $37 \%$ had HbF levels $\geq 10 \%$. Significant correlations were observed between HbF level and several clinical parameters independent of age including age at diagnosis ( $p$ value 0.013), number of hospitalisations ( $p$ value 0.024 ) and transfusions ( $p$ value 0.018 ) since birth.

Conclusion: A third of the children with SCA attending the Sickle cell clinic in Mulago Hospital have high HbF levels. Higher HbF level is associated with later onset of symptoms and presentation, and less severe disease characterised by fewer hospitalisations and blood transfusions. We suggest HbF levels should be determined at initial contact for patients with SCA to guide counselling and identify those who may need closer follow up and consideration for disease modifying drugs.
\end{abstract}

Keywords: Sickle cell anaemia (SCA), Foetal haemoglobin (HbF), Disease severity

\section{Background}

Sickle cell anaemia (SCA), the most common inheritable disease in Africa, is a leading public health problem in the region and elsewhere where descendants of Africans have settled [1]. Worldwide, it is recognized as a major cause of morbidity and mortality with tremendous social and economic impact mainly due to the recurrent acute episodic clinical events called "crises" and hospitalizations [2]. In Africa, SCA is estimated to contribute to an equivalent of $5 \%$ of under-five deaths, with up to $16 \%$ in

\footnotetext{
* Correspondence: Impalampa@yahoo.com

'Life Link Medical Centre, Kampala, Uganda

Full list of author information is available at the end of the article
}

some countries such as Nigeria and only half of the affected children live beyond their fifth birthday [3].

In Uganda, SCA is the most frequent hereditary haemolytic anaemia. Unlike the situation in developed countries, where there has been a reduction in morbidity and mortality mainly because of the availability of specialised comprehensive care in these countries [4], in Uganda there is no neonatal screening program and care is mainly supportive. The disease is therefore associated with high morbidity and mortality with about $70-80 \%$ of children with the disease dying before the age of two years [5]. Several studies in the 1950s estimated that $20 \%$ of the population had the sickle cell trait [6]. The

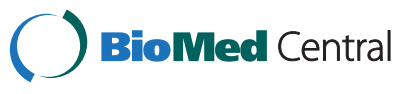


gene frequency had marked variation between different tribal groups, being highest among the Bamba (40\%), $16-20 \%$ among the Baganda, Itesot, Acholi and lowest among the Karamajong (1-4\%) [6,7].

One important factor that has been described as influencing the clinical course and hence disease severity in SCA is foetal haemoglobin ( $\mathrm{HbF}$ ) level [8]. Populations with high $\mathrm{HbF}$ levels like those in Eastern Saudi Arabia have been described as having less severe disease with fewer complications [9] and better survival [10]. Foetal haemoglobin interferes with the polymerization of $\mathrm{HbS}$ which usually occurs at low oxygen tension in patients with SCA [11]. In addition, red blood cells with higher $\mathrm{HbF}$ content have prolonged survival hence patients with high $\mathrm{Hb} F$ level also tend to have higher overall $\mathrm{Hb}$ levels [12].

As part of comprehensive care, disease-modifying drugs (DMDs), most of which act by inducing and raising $\mathrm{HbF}$ levels, are now being used to influence the clinical picture and quality of life in patients with SCA. These drugs have been shown to be beneficial especially in those with severe disease [11].

The level of $\mathrm{HbF}$ is fairly characteristic of the child's level through life after the first year of life and hence this value has been postulated to be of prognostic importance and predict survival $[10,13]$. Although the baseline HbF levels are known in several populations around the world, hardly any studies have examined HbF levels in patients in our region or how this may correlate with clinical disease severity. Such knowledge would be quite important in assessing the possible impact that introducing DMDs may have.

In this study, therefore, we aimed to determine the HbF levels in Ugandan children with SCA and examine the relationship between $\mathrm{HbF}$ level and disease severity.

\section{Methods \\ Design}

This was a cross sectional study that examined the relationship between HbF level and disease severity.

\section{Study setting}

The study was conducted at the Sickle Cell Clinic (SCC) of Mulago Hospital over a two month period from January to February 2010. Located in the capital, Kampala, Mulago is the National Referral Hospital for Uganda and teaching hospital for Makerere University College of Health Sciences The hospital has a bed capacity of 1,500 and an annual inpatient turnover of 120,000 . The SCC is the only such clinic in Uganda which provides specialized care for both children and adults with SCA. The clinic runs cost-free daily services and receives about 250-300 patients each week. It has over 6000 registered patients. Patients are registered after confirmation of homozygous SS disease by $\mathrm{Hb}$ electrophoresis on cellulose acetate membranes.

The clinic functions as a regular follow up centre and a day care centre, where non-critically ill patients are admitted for daytime management. Very ill patients are admitted to the paediatric emergency ward (Acute Care Unit) or adult medical casualty unit. The services provided include counselling, blood transfusions, and provision of medicines e.g. antimalarial prophylaxis, folic acid and analgesics. The clinic relies on volunteers for the delivery of some of the services. Disease modifying drugs such as hydroxyurea are not routinely provided for eligible patients.

\section{Study participants}

All children aged between 1 and 18 years with confirmed SCA ( $\mathrm{Hb} \mathrm{SS}$ ) attending the clinic during the study period were eligible. The age of recruitment was from one year because after the first year, the HbF level is fairly characteristic for a patient and essentially remains so throughout life [13]. All children whose parents gave a written informed consent were included in the study. We excluded from the study any child who was severely anaemic $(\mathrm{Hb}<5 \mathrm{~g} / \mathrm{dl})$. Patients who met the study criteria were consecutively enrolled daily. A sample size of 211 was calculated using Kish Leslie formula for cross sectional surveys using $17 \%$ as the expected prevalence of high $\mathrm{HbF}$ level in the cohort [14]. High $\mathrm{HbF}$ was defined as foetal haemoglobin $\geq 10 \%$ as used in earlier studies in Nigeria [14], Senegal [15] and Saudi Arabia [16].

\section{Study procedure}

Identification and screening of eligible patients was carried out by a study nurse at the reception. Parents or guardians of patients who met the selection criteria were then approached for consent by the study nurse and, in addition, assent was sought from children 8 years or older. Patients whose parents/guardians gave consent were then recruited and assigned a study number. Data from clinical history (from both parents/guardians and available in the clinical notes) and physical exam was abstracted on to a pre-designed standard case record form. The descriptions included age at onset of symptoms, number of transfusions, hospitalisations, and severe pain episodes in the past year; complications such as cerebrovascular accidents, priapism, and avascular necrosis; and findings on physical examination.

Four millilitres of peripheral venous blood was drawn for a complete blood count and foetal haemoglobin levels. The blood was put in two ethylenediaminetetraacetic acid (EDTA) bottles; one for an automated complete blood count and the second for determination of $\mathrm{Hb} \mathrm{F}$ levels by the alkali denaturation method by 
Betke [17]. This test has been used in other studies of $\mathrm{HbF}$ levels in populations in Nigeria by Fatunde et al [14], and in Senegal by Diop et al [15]. The basis of this test is that foetal haemoglobin $(\mathrm{HbF})$ is more resistant to denaturation in alkaline solution than adult haemoglobin (HbA). Alkali converts $\mathrm{HbA}$ to alkaline hematin. Alkaline hematin is insoluble and precipitates. $\mathrm{HbF}$ is quantitated by measuring the haemoglobin concentration before and after denaturation. The procedure involves treating a cyanmethaemoglobin solution with $1.2 \mathrm{~N}$ sodium hydroxide. Saturated ammonium sulphate is used to neutralise the alkali after 2 minutes and the mixture is filtered, read at $420 \mathrm{~nm}$ and compared with an adequate dilution of the original cyanmethaemoglobin solution in water. All samples were analysed on the collection day.

\section{Data analysis}

All case record forms were checked for completeness and accuracy before each participant left the clinic. The corrected forms were then kept in a study file. The data recorded on each form was then entered into a database using EPI-data version 3.1 package using double data entry to ensure correctness. Data was exported to and analysed using STATA version 10 software (STATA Coop, TX). Proportions were compared using Pearson's chi square test and reported with the odds ratios with 95\% confidence intervals.

Normally distributed continuous variables were summarized as means and compared using the student's $t$ test while the median was used for skewed data and compared using the Mann Whitney U / Rank sum test. In all cases, $\mathrm{p}$ values $<0.05$ was considered significant.

\section{Ethical considerations}

Approval to conduct the study was obtained from Makerere University School of Medicine Research and Ethics Committee. Written informed consent was obtained from legal caretakers of participants and assent was sought from participants aged 8 years and above before enrolment into the study. Enrolment was voluntary and participants could withdraw from the study at any time without consequences to the patient. Results of the investigations and any additional important information were availed to the primary physicians taking care of the study participants.

\section{Results and discussion Results}

Over a two month period, from January to February 2010, five hundred and sixty eight patients attended the Sickle cell clinic in Mulago Hospital and 216 met our eligibility criteria and were enrolled. Of the 216 study subjects, 115 (53.2\%) were female and 101 (46.8\%) male.
The mean (SD) age was 9.3 (4.8) years and the median age 9 (IQR 5-13) years. The characteristics of the study participants are summarised in Table 1

\section{Foetal haemoglobin levels}

The mean HbF level of the participants was 9.0\% (SD 5.58 ) and the median was $7.9 \%$ (IQR 4.7-12.4\%). Eighty patients $(37.0 \%)$ had high levels of $\mathrm{Hb} \mathrm{F}(\geq 10 \%)$. The majority of the participants had HbF levels between 2 and $11 \%$ with very few having levels greater than $20 \%$. Patients 5 years and younger on average had higher $\mathrm{HbF}$ levels [mean $\mathrm{HbF} 11.9 \%$ (SD 5.69)] compared to older patients [mean HbF 7.9\% (SD 5.13)] although this difference was not statistically significant ( $p$ value 0.843 ).

Overall, high HbF level was associated with less severe disease. In the past year, children with high HbF levels had significantly fewer hospitalisations ( $p$ value 0.036 ) as well as fewer transfusions and painful episodes, but this relationship was not statistically significant (Table 2). Furthermore, patients with high $\mathrm{HbF}$ were less likely to have had dactylitis or stroke; and of the patients who developed dactylitis, patients with high $\mathrm{HbF}$ levels were more likely to develop this at an older age, but this relationship was not statistically significant. There were only 2 patients with avascular necrosis and both had low $\mathrm{HbF}$ levels and 3 with a history of priapism, of which 2 had low levels HbF levels.

However, when the relationship between $\mathrm{HbF}$ level as a continuous variable and some of the markers of disease severity was examined, a statistically significant negative correlation was observed between $\mathrm{HbF}$ level and participant age $(\mathrm{r}=-0.299$, $\mathrm{p}$ value $=<0.0001)$, the total number of transfusions $(r=-0.181$, $\mathrm{p}$ value 0.004$)$, all cause hospitalisations $(r=-0.173, \mathrm{p}$ value 0.006$)$, and number of severe pain episodes in the past year $(r=$ $-0.104, \mathrm{p}$ value 0.020$)$. The association between $\mathrm{HbF}$ and age at diagnosis $(\mathrm{r}=0.151, \mathrm{p}$ value 0.013$)$, all cause hospitalisations $(\mathrm{r}=-0.135$, $\mathrm{p}$ value 0.024$)$ and need for transfusions ( $\mathrm{r}=-0.144, \mathrm{p}$ value 0.018 ) since birth remained significant even when this was adjusted for age of the participants Table 3 .

\section{Discussion}

The influence of foetal haemoglobin levels on disease manifestation in SCA has hardly been studied in East Africa. The objective of our study was to examine the relationship between $\mathrm{HbF}$ level and disease severity among patients with SCA attending the Sickle cell clinic in Mulago Hospital, Uganda. We found that over one third of the patients studied had high levels of $\mathrm{Hb} F$ and that higher levels were associated with less severe disease. In particular, higher levels were associated with older age at diagnosis, fewer all cause hospitalisations, transfusions and severe pain episodes. 
Table 1 Clinical characteristics of SCA patients by HbF level

\begin{tabular}{|c|c|c|c|c|}
\hline Characteristic & $\begin{array}{l}\text { Patients with High HbF } \\
\text { levels }(\geq 10 \%) \mathrm{N}=80(\%)\end{array}$ & $\begin{array}{l}\text { Patients with low HbF } \\
\text { levels }(<10 \%) \mathrm{N}=136(\%)\end{array}$ & OR $(95 \% \mathrm{Cl})$ & $p$ value \\
\hline \multicolumn{5}{|c|}{ Demographic features } \\
\hline \multicolumn{5}{|l|}{ Gender } \\
\hline Female & $48(60 \%)$ & $67(49.3 \%)$ & $1.54(0.88-2.71)$ & 0.128 \\
\hline Male & $32(40 \%)$ & $69(50.7 \%)$ & & \\
\hline \multicolumn{5}{|l|}{$\overline{\text { Age }}$} \\
\hline$<5$ years & $28(35 \%)$ & $20(14.7 \%)$ & $3.12(1.58-6.17)$ & 0.0005 \\
\hline$\geq 5$ years & $52(65 \%)$ & $116(85.3 \%)$ & & \\
\hline \multicolumn{5}{|l|}{ HISTORY } \\
\hline \multicolumn{5}{|c|}{ Reason for clinic visit } \\
\hline Sick visit & $63(77 \%)$ & $100(73.5 \%)$ & $1.33(0.69-2.57)$ & 0.390 \\
\hline Routine visit & $17(23 \%)$ & $36(26.5 \%)$ & & \\
\hline \multicolumn{5}{|c|}{ Duration of follow up in SCC } \\
\hline$<5$ years & $54(67.5 \%)$ & $52(38.2 \%)$ & $3.36(1.83-6.16)$ & $<0.001$ \\
\hline$\geq 5$ year & $26(32.5 \%)$ & $84(61.8 \%)$ & & \\
\hline \multicolumn{5}{|c|}{ Transfusions since birth } \\
\hline$\overline{<3}$ & $58(72.5 \%)$ & $83(61 \%)$ & $1.68(0.91-3.08)$ & 0.080 \\
\hline$\geq 3$ & $22(27.5 \%)$ & $53(39 \%)$ & & \\
\hline \multicolumn{5}{|c|}{ Hospitalisations since birth } \\
\hline$\leq 2$ & $48(60 \%)$ & $61(55 \%)$ & $1.82(1.03-3.21)$ & 0.036 \\
\hline$>2$ & $32(40 \%)$ & $75(45 \%)$ & & \\
\hline \multicolumn{5}{|l|}{ SIGNS } \\
\hline \multicolumn{5}{|l|}{ Jaundice } \\
\hline present & $53(66.3 \%)$ & $85(62.5 \%)$ & $1.18(0.66-2.11)$ & 0.580 \\
\hline absent & $27(33.7 \%)$ & $51(37.5 \%)$ & & \\
\hline \multicolumn{5}{|c|}{ Palpable spleen } \\
\hline Yes & $24(30 \%)$ & $28(20.6 \%)$ & $1.65(0.87-3.13)$ & 0.119 \\
\hline No & $56(60 \%)$ & $108(79.4 \%)$ & & \\
\hline \multicolumn{5}{|l|}{ Hepatomegaly } \\
\hline Present & $40(50 \%)$ & $60(44.1 \%)$ & $1.27(0.73-2.21)$ & 0.404 \\
\hline absent & $40(50 \%)$ & $76(55.9 \%)$ & & \\
\hline \multicolumn{5}{|c|}{ Haematological parameters } \\
\hline \multicolumn{5}{|l|}{ WBC count } \\
\hline$<15.0$ & $35(43.8 \%)$ & $65(47.8 \%)$ & $1.18(0.67-2.05)$ & 0.566 \\
\hline$\geq 15.0$ & $45(56.2 \%)$ & $71(52.2 \%)$ & & \\
\hline \multicolumn{5}{|l|}{ RBC count } \\
\hline$<3.0$ & $48(60 \%)$ & $80(58.8 \%)$ & $1.05(0.60-1.85)$ & 0.865 \\
\hline$\geq 3.0$ & $32(40 \%)$ & $56(41.2 \%)$ & & \\
\hline \multicolumn{5}{|l|}{$\mathrm{Hb}$ level } \\
\hline$\geq 7 \mathrm{~g} / \mathrm{dl}$ & $60(75 \%)$ & $98(72.1 \%)$ & $1.16(0.62-2.19)$ & 0.638 \\
\hline$<7 \mathrm{~g} / \mathrm{dl}$ & $20(25 \%)$ & $38(27.9 \%)$ & & \\
\hline \multicolumn{5}{|l|}{ PLT level } \\
\hline$<400$ & $40(50 \%)$ & $66(48.5 \%$ & $1.06(0.61-1.85)$ & 0.835 \\
\hline$\geq 400$ & 40 (50\%) & $70(51.5 \%)$ & & \\
\hline
\end{tabular}


Table 2 Features of disease severity by HbF level

\begin{tabular}{|c|c|c|c|c|}
\hline Clinical features & $\begin{array}{l}\text { Patients with High HbF } \\
\text { levels }(\geq 10 \%) \mathrm{N}=80(\%)\end{array}$ & $\begin{array}{l}\text { Patients with low HbF } \\
\text { levels }(<10 \%) \mathrm{N}=136(\%)\end{array}$ & OR $(95 \% \mathrm{Cl})$ & $p$ value \\
\hline \multicolumn{5}{|c|}{ History of dactylitis } \\
\hline Present & $53(66.3 \%)$ & $106(77.9 \%)$ & & \\
\hline Absent & $27(33.7 \%)$ & $30(22.1 \%)$ & $1.80(0.97-3.53)$ & 0.060 \\
\hline \multicolumn{5}{|c|}{ Age at onset of dactylitis } \\
\hline$<1$ year & $37(69.8 \%)$ & $78(73.6 \%)$ & & \\
\hline$\geq 1$ year & $16(30.2 \%)$ & $28(26.4 \%)$ & $1.20(0.57-2.50)$ & 0.617 \\
\hline \multicolumn{5}{|l|}{ Age at diagnosis } \\
\hline$\leq 1$ year & $31(38.8 \%)$ & $54(40 \%)$ & & \\
\hline$>1$ year & $49(61.2 \%)$ & $81(60 \%)$ & $1.05(0.59-1.86)$ & 0.857 \\
\hline \multicolumn{5}{|c|}{ Hospitalisations in past year } \\
\hline No & $40(50 \%)$ & $63(46.3 \%)$ & $1.16(0.67-2.02)$ & 0.602 \\
\hline yes & $40(50 \%)$ & $73(53.7 \%)$ & & \\
\hline \multicolumn{5}{|c|}{ Transfusions in past year } \\
\hline No & $62(77.5 \%)$ & $92(67.7 \%)$ & $1.65(0.87-3.13)$ & 0.123 \\
\hline Yes & $18(22.5 \%)$ & $44(32.3 \%)$ & & \\
\hline \multicolumn{5}{|c|}{ Painful episodes in past year } \\
\hline No & $27(33.7 \%)$ & $41(30.1 \%)$ & $1.18(0.65-2.13)$ & 0.583 \\
\hline Yes & $53(66.3 \%)$ & $95(69.9 \%)$ & & \\
\hline \multicolumn{5}{|l|}{ History of stroke } \\
\hline No & $76(95 \%)$ & $123(90.4 \%)$ & $2.00(0.63-6.43)$ & 0.231 \\
\hline Yes & $4(5 \%)$ & 13 (9.6\%) & & \\
\hline
\end{tabular}

The proportion of patients with high HbF levels, 37\%, was higher than what was observed in West Africa, particularly Senegal (25\%) [15] and Nigeria (17\%) [14]. This is surprising because patients from Senegal are thought to have the Senegal haplotype, which is thought to be associated with a higher $\mathrm{HbF}$ level. One difference is that the Dakar study had adult participants and this may account for the slight difference in $\mathrm{Hb} F$ levels, even though $\mathrm{Hb} \mathrm{F}$ levels are thought to be fairly stable after the first year of life.

The average $\mathrm{HbF}$ level in our population was 9.0\% which is comparable to other studies in Congo [18], Nigeria [19], and Saudi Arabia [16] where the mean Hb F levels were $8.8 \%, 9.5 \%$ and $9.1 \%$ respectively.

The relatively higher levels of $\mathrm{Hb} \mathrm{F}$ in the current study may be a possible indicator that those with low

Table 3 Correlation between some of the cinical characteristics and HbF levels

\begin{tabular}{|c|c|c|c|c|}
\hline \multirow[t]{2}{*}{ Variable } & \multirow{2}{*}{$\frac{\text { HbF Levels }}{\text { Pearson Coefficient }}$} & \multirow[t]{2}{*}{ p-value } & \multicolumn{2}{|l|}{ Adjusted for age } \\
\hline & & & Pearson Coefficient & $p$-value \\
\hline Age & -0.299 & 0.000 & - & - \\
\hline Age at diagnosis of SCA & 0.047 & 0.245 & 0.151 & 0.013 \\
\hline Age at onset of dactylitis & -0.038 & 0.291 & 0.109 & 0.086 \\
\hline Number of hospitalisations since diagnosis & -0.173 & 0.006 & -0.135 & 0.024 \\
\hline Number of transfusions since diagnosis & -0.181 & 0.004 & -0.144 & 0.018 \\
\hline Number of intra-muscular injections received in past year & -0.140 & 0.020 & -0.099 & 0.075 \\
\hline Number of hospitalizations in the past year & -0.068 & 0.161 & -0.104 & 0.064 \\
\hline Number of blood transfusions in the past year & -0.038 & 0.291 & -0.071 & 0.149 \\
\hline WBC Count & 0.074 & 0.138 & -0.023 & 0.367 \\
\hline $\mathrm{Hb}$ levels & -0.003 & 0.480 & 0.024 & 0.364 \\
\hline PLT levels & -0.105 & 0.061 & -0.105 & 0.062 \\
\hline
\end{tabular}


HbF have more severe disease and die very young from complications of SCA even before the diagnosis is established. This way, only the survivors are seen in the clinic and are now classified as having high $\mathrm{Hb} F$ levels and possibly less severe disease. A prospective study of a birth cohort and neonatal diagnosis will be able to clarify this assertion.

The mean age at diagnosis in this study was 2.8 (SD 2.9) years which is much younger than that in the Dakar [15] study which was 9.8 years with only $56.7 \%$ of their patients diagnosed by 10 years while $83 \%$ of the children in this study were diagnosed by 5 years. The differences in age at diagnosis could be because this region in East Africa is a malaria endemic area and children with sickle cell are more likely to present with some of the complications of falciparum malaria such as severe malaria anaemia and may be tested and diagnosed early. There is also a relatively high prevalence of sickle cell disease and perhaps the index of suspicion is higher among the clinicians here.

Just about $70 \%$ of our study participants had at least one episode of severe pain requiring a visit to hospital in the previous year. This is less than the $90 \%$ observed in the Dakar study. One possibility is that the study included young children who may not be able to articulate the severity of their pain clearly, and so the caretakers may not bring them to hospital for pain. We found that the number of pain episodes was significantly related to the HbF levels which is similar to what Platt found that low $\mathrm{HbF}$ levels were significantly associated with number of pain episodes per year [20].

Complications such as cerebrovascular accidents (CVA), avascular necrosis and priapism were reported in only $10 \%$ of the study participants which is lower than what was found in Dakar (25\%) [15] possibly because many of these occur in older patients. The Dakar study also had a smaller sample size of 60 patients and participants were prospectively followed up. Of key interest was that the Dakar study did not report any incident of CVA and yet this was the main complication in the present study. However, when our geographic location is put into consideration, this is where the Bantu haplotype is mainly found, and this has been associated with more severe disease.

Only $32 \%$ of the patients had never received a blood transfusion which is less than half of what was described in Dakar where $68.3 \%$ of their patients had never been transfused. The difference in $\mathrm{HbF}$ levels between those who had never been transfused and those who had received a transfusion was not statistically significant. One possibility why so many of the children have received transfusion may be the high malaria transmission in the country.

Although the relationship between high $\mathrm{HbF}$ as a categorical value and several markers of disease severity was not statistically significant, when the correlation between $\mathrm{HbF}$ levels as a continuous variable and the same markers of disease severity was examined, a significant relationship was clearly observed with the age at diagnosis of SCA, the number of transfusions, hospitalisations and the number of severe pain episodes in the past year. A mathematical modelling of the data may help in determining the minimum cut-off $\mathrm{HbF}$ level in our setting that may be associated with less severe disease. Knowledge of such a level will be important for designing trials of treatments that are used to raise $\mathrm{HbF}$ level.

This study had a number of limitations. Many of the markers of disease severity depended on the participants' ability to remember events in the past. Thus, the ability to recall some of these clinical events and the unavailability of some medical records to ascertain the severity of symptoms may have affected our results. Any documentation would have been useful in defining the actual diagnosis for the previous admissions. Secondly, children who were severely anaemic at enrolment were excluded because the method of estimation of $\mathrm{HbF}$ level would be inaccurate when the $\mathrm{Hb}$ level is below $5 \mathrm{~g} / \mathrm{dl}$. This means some of the patients with severe disease may have been excluded. We also included all four patients who had been started on hydroxyurea; however, they had been on this therapy for a median of two weeks, and so the effect on HbF level would be minimal. Lastly, we did not examine for thalassemia and sickle cell haplotypes which may influence disease severity.

\section{Conclusions}

One third of the patients with sickle cell anaemia in Mulago Hospital have high levels of $\mathrm{HbF}$. High $\mathrm{HbF}$ is associated with less severe disease independent of age; including age at diagnosis, number of all cause hospitalisations and transfusions. We suggest that $\mathrm{HbF}$ levels should form part of the initial investigations in patients with sickle cell anaemia as this may have value in counselling on patient follow up, prognosis and also consideration for the preferential use of hydroxyurea. A mathematical modelling of the data from this study may help in determining the minimum cut-off $\mathrm{HbF}$ level in our setting associated with less severe disease. This level may be aimed at especially when considering treatments that are used to raise $\mathrm{HbF}$ level.

\section{Abbreviations}

SCA: Sickle cell anaemia; SCC: Sickle cell clinic; HbF: Foetal haemoglobin.

\section{Competing interests}

The authors declare that they have no competing interests.

\section{Authors' contributions}

$L M, C M N, R I \& H D$ contributed to the design of the study and assisted with data analysis. LM coordinated the study and supervised the enrolment of 
patients. All authors contributed to the interpretation of data, preparation of the manuscript and approved the final version.

\section{Authors' information}

LM: MBChB, M.Med (Paed)

CMN: MBChB, M.Med (Paed) is the head of the Sickle Cell Clinic in Mulago Hospital.

RI: MBChB, M.Med (Paed), PhD is a Paediatric neurologist in Mulago hospital and Clinical Research Paediatrician with the centre for Tropical Medicine, University of Oxford

HD: MBChB, M.Med (Int Med) is a haematologist in Mulago Hospital.

\section{Acknowledgements}

We acknowledge the help of all the staff in Sickle Cell Clinic, colleagues in the department of Pediatrics (MakCHS) and Ms. D. Namujju for all the assistance in statistical analysis.

\section{Author details}

'Life Link Medical Centre, Kampala, Uganda. ${ }^{2}$ Department of Paediatrics, Makerere University, College of Health Sciences, Kampala, Uganda. ${ }^{3}$ Department of Medicine and Uganda Cancer Institute, Mulago Hospital, Kampala, Uganda. ${ }^{4}$ Department of Paediatrics, Mulago Hospital/ Makerere University, College of Health Sciences, Kampala, Uganda. ${ }^{5}$ Centre for Tropical Medicine, Nuffield Department of Medicine, Oxford University, Oxford, UK.

Received: 28 February 2012 Accepted: 31 August 2012

Published: 7 September 2012

\section{References}

1. Roberts I, Montalembert M: Sickle cell disease as a paradigm of immigration hematology: new challenges for hematologists in Europe. Haematologica 2007, 92:865-871.

2. Sickle cell disease in the African Region: Current situation and the way forward. Report of the Regional Director. In Regional Committee for Africa. Addis Ababa: World Health Organisation; 2006.

3. Sickle-cell anaemia, Report by the Secretariat. World Health Organisation; 2006.

4. Lane PA, Buchanan GR, Hutter JJ, Austin RF, Britton HA, Rogers ZR, Eckman $J R$, DeBaun MR, Wang WC MP, et al: Sickle cell disease in children and adolescents: diagnosis, guidelines for comprehensive care, and care paths and protocols for management of acute and chronic complications. 2001.

5. Ndugwa CM, Serjeant G: Sickle cell anaemia in Uganda: A time for Action. East Afr Med J 2003, 80:384-387.

6. Lehmann H, Raper AB: Distribution of sickle cell Trait in Uganda and it's ethnological significance. Nature 1949, 164:494-495.

7. Trowell HC: Sickle cell anaemia. East Afr Med J 1945, 23:34-45.

8. Charache S: Fetal hemoglobin, sickling, and sickle cell disease. Adv Pediatrics 1990, 37:1-31.

9. Perrine RP, Pembrey ME, John P, Perrine S, Shoup F: Natural History of Sickle Cell Anemia in Saudi Arabs; A Study of 270 Subjects. Ann Intern Med 1978, 88:1-6.

10. Platt OS, Brambilla DJ, Rosse WF, Milner PF, Castro O, Steinberg MH, Klug PP: Mortality In Sickle Cell Disease - Life Expectancy and Risk Factors for Early Death. N Engl J Med 1994, 330:1639-1644.

11. Trompeter S, Roberts I: Haemoglobin F modulation in childhood sickle cell disease. Br J Haematol 2008, 144:308-316.

12. Franco RS, Yasin Z: The effect of fetal hemoglobin on the survival characteristics of sickle cells. Blood 2006, 108:1073-1076

13. Bailey K, Morris JS, Thomas P: Fetal haemoglobin and early manifestations of homozygous sickle cell disease. Arch Dis Child 1992, 67:517-520.

14. Fatunde OJ, Scott-Emuakpor AB: Foetal haemoglobin in Nigerian children with sickle cell anaemia. Effect on haematological parameters and clinical severity. Trop Geogr Med 1992, 44:264-266.

15. Diop S, Thiam D, Cisse M, Toure-Fall AO, Fall K, Diakhate L: New results in clinical severity of homozygous sickle cell anemia in Dakar, Senegal. Hematol Cell Ther 1999, 41:2217-2221.

16. El-Hazmi MAF: Clinical and Haematological Diversity of Sickle cell disease in Saudi Children. J Trop Pediatr 1992, 38:106-112.

17. Prehu C, Ducrocq R, Godart C, Riou J, Galacteros F: Determination of $\mathrm{Hb}$ F Levels: The Routine Methods. Hemoglobin 1998, 22:459-467.
18. Mouele R, Galacteros F, Feingold J: Haemoglobin F ( $\mathrm{HbF}$ ) levels in sickle-cell anaemia patients homozygous for the Bantu haplotype. Eur J Haematol 1999, 63:136-137.

19. Fatunde OJ, Scott-Emuakpor AB: Haemoglobin F and A2 in Nigerian children with sickle cell anaemia. J Trop Pediatr 1993, 39:251-252.

20. Platt OS, Thorington BD, Brambilla DJ, Milner PF, Rosse WF, Vichinsky E, Kinney TR: Pain in sickle cell disease. Rates and risk factors. N Engl J Med 1991, 325:11-16.

doi:10.1186/1471-2326-12-11

Cite this article as: Mpalampa et al:: Foetal haemoglobin and disease severity in sickle cell anaemia patients in Kampala, Uganda. BMC Blood Disorders 2012 12:11.

\section{Submit your next manuscript to BioMed Central and take full advantage of:}

- Convenient online submission

- Thorough peer review

- No space constraints or color figure charges

- Immediate publication on acceptance

- Inclusion in PubMed, CAS, Scopus and Google Scholar

- Research which is freely available for redistribution

Submit your manuscript at www.biomedcentral.com/submit
C Biomed Central 